\title{
Communication \\ The Repeatability of Grazing Efficiency as a Perennial Ryegrass Variety Trait
}

\author{
Tomás Tubritt ${ }^{1, *}$, Luc Delaby $^{2}$ and Michael O'Donovan $^{1}$
}

1 Teagasc Animal and Grassland Research and Innovation Centre, Teagasc, Moorepark, Fermoy, P61 C996 Co. Cork, Ireland; michael.odonovan@teagasc.ie

2 INRAE, AgroCampus Ouest, Physiologie Environnement et Génétique pour l'Animal et les Systèmes d'Elevage, F-35590 Saint-Gilles, France; luc.delaby@inrae.fr

* Correspondence: tomas.tubritt@teagasc.ie

Citation: Tubritt, T.; Delaby, L.; O'Donovan, M. The Repeatability of Grazing Efficiency as a Perennial Ryegrass Variety Trait. Agronomy 2022, 12, 577. https://doi.org/ 10.3390/agronomy12030577

Academic Editor: Martin Gierus

Received: 24 January 2022

Accepted: 21 February 2022

Published: 25 February 2022

Publisher's Note: MDPI stays neutral with regard to jurisdictional claims in published maps and institutional affiliations.

Copyright: (C) 2022 by the authors. Licensee MDPI, Basel, Switzerland. This article is an open access article distributed under the terms and conditions of the Creative Commons Attribution (CC BY) license (https:// creativecommons.org/licenses/by/ $4.0 /$ )

\begin{abstract}
The 'Grazing Utilization' sub-index within the Pasture Profit Index identifies perennial ryegrass varieties with high grazing efficiency. Grazing efficiency is assessed in plot trials conducted over a number of years. The objective of this study was to investigate the repeatability of variety grazing efficiency. Correlations were derived between variety performance in separate evaluation years and between variety performances in separate trials. Grazing efficiency was found to be moderately repeatable, with correlation values ranging from 0.47 to 0.86 between years and ranging from 0.51 to 0.84 between trials. The results will provide commercial seed companies with increased confidence when developing variety mixes intended for intensive grazing. Farmers will benefit from improved variety selection and animal performance from their farms.
\end{abstract}

Keywords: perennial ryegrass; variety; grazing efficiency; repeatability

\section{Introduction}

Employing grassland management techniques that increase the quantity and quality of pasture fed to dairy cows increases farm productivity and net profit [1,2]. Grazing to low post-grazing heights (about $4 \mathrm{~cm}$ ) is a grassland management technique used by commercial farmers to maintain/increase sward quality during the grazing season [3]. Commercial farmers in Ireland reported that certain perennial ryegrass (PRG) varieties were easier to graze to these target post-grazing heights and thus eased grassland management on these farms [4]. Variety grazing efficiency was assessed over a number of years in plot trials [5]. These evaluations used grazing dairy cows to defoliate variety plots, which differs from traditional protocols that use mechanical harvesting machinery to assess variety herbage yield and digestibility parameters [6,7]. Using grazing animals to assess variety performance provides a better reflection of the environment in which perennial ryegrass varieties are exposed to on a farm in Ireland, where grazed grass makes up $75 \%$ of a cow's annual diet [8].

Prior to pasture reseeding, farmers had no indication whether the varieties available for reseeding will be grazing efficient or grazing inefficient and therefore it was necessary to include a grazing efficiency trait in the Pasture Profit Index (PPI). The PPI is a variety selection tool used in Ireland that identifies the best varieties for dairy farms based on variety performance in a number of agronomically relevant traits [9]. The 'Grazing Utilization' trait was included in the PPI in 2021 and identifies grazing efficient and grazing inefficient varieties [10].

Perennial ryegrass grazing efficiency is a relatively new variety trait. Sufficient data now exist to determine whether current the evaluation protocols are sufficient to identify superior grazing efficient varieties. The objective of this study was to use evaluation data to assess how repeatable grazing efficiency is as a PRG trait. The investigation focused on 
how grazing efficiency is repeatable throughout the lifetime of a variety within a trial and also between evaluation trials.

\section{Materials and Methods}

Variety grazing efficiency was assessed in Teagasc Moorepark, in the South West of Ireland $\left(50^{\circ} 70^{\prime} \mathrm{N}, 8^{\circ} 16^{\prime} \mathrm{W}\right)$. Relatively large $(8 \mathrm{~m} \times 4.5 \mathrm{~m})$ plots were sown in a complete randomized block design. These plots were rotationally grazed by a herd of dairy cows; the swards were grazed when the average herbage mass across the collection of plots was estimated to be $1400 \mathrm{~kg}$ DM/ha [11]. The trial was grazed from February to November with 8 to 10 grazing rotations taking place. Pre-grazing measurements, including individual plot herbage mass and pre-grazing height, were recorded. Herbage mass was measured from mechanical harvests taken from a sub-section of each plot as described by [12]. Pre-grazing sward height was recorded with a rising plate meter (Jenquip, Fielding, New Zealand) as described by [13]. The herd then entered the trial plots and cows had free choice to graze whichever plot they chose. When the average post-grazing height of the sward was estimated to be $4 \mathrm{~cm}$, cows were removed and individual post-grazing height was recorded from each plot in the same manner as pre-grazing height. The pre-grazing harvest subsection was rotated across three discrete areas of each plot such that rejected herbage from previous grazing events was removed once every three rotations. Therefore, cows were presented with herbage from a section of each plot that was previously cut and herbage from a section that was previously grazed.

Despite the same regrowth intervals between grazing events (harvests), variety plots differed in pre-grazing height/herbage mass at each grazing event due to the influence of variety genetics and previous grazing effects (i.e., differences in post-grazing height). The differences in pre-grazing traits influenced subsequent grazing efficiency, with higher pregrazing height/mass leading to higher post-grazing height. These pre-grazing differences between varieties needed to be accounted for to accurately assess grazing efficiency of varieties. A regression model was created that predicted the post grazing height of a variety based on that variety's pre-grazing height, such that varieties with higher pre-grazing heights were predicted to have higher post-grazing heights. The predicted post-grazing height of a variety was subtracted from the actual post-grazing height achieved in trial to create the residual grazed height (RGH) of that variety [14]. If a variety's actual postgrazing height is lower than predicted, the resulting RGH value is negative and that variety is grazing efficient; if a variety's actual post-grazing height is greater than predicted, the resulting RGH value is positive and that variety is grazing inefficient.

To determine the repeatability of variety grazing efficiency, four studies evaluating variety grazing efficiency were analyzed. All studies were conducted as outlined above. Studies differed in sowing years, harvest years, and varieties, although there was some overlap between harvest years and varieties. Three of the studies had data for 3 or more harvest years while Study 4 only had 1 year of data. The studies differed in the number of varieties evaluated, with Study 1, Study 2, Study 3, and Study 4 evaluating 59, 30, 23, and 15 varieties, respectively. The statistical program SAS 9.4 (SAS Institute Inc, Cary, NC, USA) was used to analyze correlations between harvest years (i.e., within trial). Correlations between studies (i.e., between varieties sown in different sowing years) were also determined. PROC CORR was used to determine correlations with both Pearson's and Spearman's rank investigated.

\section{Results}

A moderate correlation was found between harvest years for RGH, with average Pearson's correlations of 0.47 to 0.66 found for Study 1 (Table 1). Similar values were found for Studies 2 and 3, with Pearson's correlation values ranging from 0.48 to 0.86 and 0.58 to 0.66 , respectively. Spearman's rank correlation between years was also moderate, with average values across years within Studies 1,2, and 3 of $0.61,0.67$, and 0.64 , respectively. 
Table 1. Average Pearson's and Spearman's rank correlations between evaluation years within trials.

\begin{tabular}{|c|c|c|c|c|c|c|}
\hline \multicolumn{7}{|c|}{ Study 1 (2015-2018) } \\
\hline & \multicolumn{2}{|c|}{2016} & \multicolumn{2}{|c|}{2017} & \multicolumn{2}{|c|}{2018} \\
\hline 2015 & $0.63^{1}$ & $0.66^{2}$ & 0.60 & 0.61 & 0.55 & 0.62 \\
\hline 2016 & - & - & 0.66 & 0.65 & 0.59 & 0.63 \\
\hline 2017 & - & - & - & - & 0.47 & 0.46 \\
\hline \multicolumn{7}{|c|}{ Study 2 (2017-2019) } \\
\hline & \multicolumn{2}{|c|}{2017} & \multicolumn{2}{|c|}{2018} & \multicolumn{2}{|c|}{2019} \\
\hline 2017 & - & - & 0.86 & 0.85 & 0.48 & 0.56 \\
\hline 2018 & - & - & - & - & 0.49 & 0.60 \\
\hline \multicolumn{7}{|c|}{ Study 3 (2019-2021) } \\
\hline & \multicolumn{2}{|c|}{2019} & \multicolumn{2}{|c|}{2020} & \multicolumn{2}{|c|}{2021} \\
\hline 2019 & - & - & 0.62 & 0.69 & 0.58 & 0.66 \\
\hline 2020 & - & - & - & - & 0.66 & 0.56 \\
\hline
\end{tabular}

${ }^{1}$ Values in the left column (within year) are the Pearson's correlation coefficients. ${ }^{2}$ Values in the right column (within year) are the Spearman's rank correlation coefficients.

Pearson's correlations between varieties evaluated within different studies (i.e., between sowing years) were moderately strong, ranging from 0.51 to 0.84 (excluding trials with less than three common varieties; Table 2). The greatest correlation was seen between Study 1 and Study 2 at 0.84 , with 14 varieties common between these studies (Figure 1). The lowest correlation was seen between Study 1 and Study 3 at 0.51, with eight varieties common between both trials. When the average RGH of varieties across all evaluation studies was compared to the individual study results, Pearson correlations were high (ranging from 0.86 to 0.94$)$. Similar results were found for Spearman's rank correlation between varieties ranging from 0.43 to 0.88 (excluding trials with fewer than three common varieties). Again, comparing average variety RGH across trials to individual trial performance resulted in high Spearman's rank correlations (from 0.89 to 0.95 ).

Table 2. Pearson's correlation between perennial ryegrass variety residual grazed height, evaluated in separately sown plot evaluations (differing sowing years) and the average residual grazed height value for each variety across all trials.

\begin{tabular}{cccccc}
\hline Trial & Study $\mathbf{1}$ & Study $\mathbf{2}$ & Study $\mathbf{3}$ & Study $\mathbf{4}$ & Average \\
\hline Study 1 & - & $0.84(14)^{1}$ & $0.51(8)$ & $1.0(2)$ & $0.94(21)$ \\
Study 2 & - & - & $1.0(2)$ & $0.64(3)$ & $0.93(3)$ \\
Study 3 & - & - & - & $0.83(5)$ & $0.91(5)$ \\
Study 4 & - & - & - & - & $0.86(6)$ \\
\hline
\end{tabular}

${ }^{1}$ Values in brackets indicate the number of varieties common between trials.

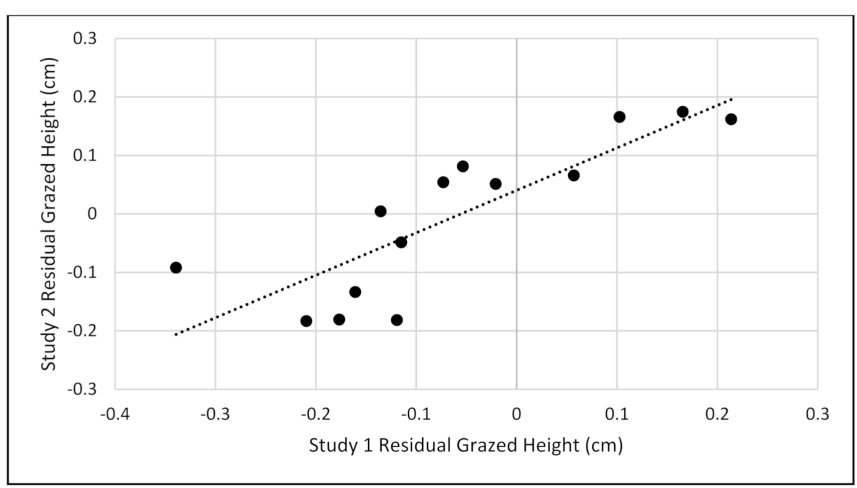

Figure 1. Relationship between varieties common to Study 1 and Study 2 for residual grazed height $(r=0.84)$. 


\section{Discussion}

The repeatability estimates of grazing efficiency ranged from 0.47 to 0.66 . The results are similar to repeatability estimates of other PRG traits with $[15,16]$ finding similar repeatability values for PRG herbage yield and PRG digestibility, respectively. The large ranges in correlations between some years were similar to those reported in [15], which found mean rank correlations of 0.46 and 0.72 between the first and third year and second and third year DM yield evaluations, respectively. Such results show that while one-year evaluation results may provide an indication of a variety's agronomic potential for a trait, the inclusion of additional evaluation year(s) is necessary before recommendations, etc., can be fully determined. Ref. [17] found that first year DM yield results were less reflective of lifetime variety performance than second harvest year results, further emphasizing the importance of including additional harvest years.

The variances in variety herbage yield between harvest years can be explained by differences in the meteorological conditions between years, which has a large effect on PRG herbage growth [18]. Despite this, evidence suggests that PRG varieties do not differ in their levels of drought tolerance as rank correlation between varieties for herbage yield is maintained [14]. The effect of weather on grazing efficiency is likely to be less than that of herbage yield as plant growth structure/morphology has a greater influence on grazing efficiency [19]. Ref. [20] found that varieties with higher levels of digestibility and leaf proportion had greater grazing efficiency, which agrees with [5,21]. Plant growth structure is greater influenced by variety genetics, while weather conditions determine the rate at which this growth structure is expressed [22]. Considering this, yearly variation in grazing efficiency may be expected to be less than that of herbage yield. Further investigations are needed to determine the extent to which plant growth habit is repeated in subsequent years of evaluation. Ref. [23] hypothesized that PRG plants concentrate resources into the rapid production of leaf in the first production year, but place a greater emphasis on root development for storage in the second year. This explained why a decline in yield is often observed in the second production year of a sward. Animal grazing of grass swards also influences their morphology [24], but it may require successive grazings for a sward to reach a consistent morphology. Investigations should focus on how perennial ryegrass growth strategy and morphology change from establishment to maturity.

The strong correlation observed between varieties sown in differing trials adds further evidence that grazing efficiency is a repeatable PRG trait. The inclusion of an additional sowing year to a variety's overall RGH value provides a high level of accuracy. Promising candidate varieties should be assessed under grazing for a minimum of 2 years prior to recommendation to give an indication of a variety's grazing potential. Once a variety is recommended, a second sowing/evaluation should be conducted to increase the robustness of variety grazing efficiency evaluation. Variety evaluation in Ireland has progressed over the past decade and now large trial networks and datasets exist. The on-farm variety evaluation study [4] is an example of such networks. An interesting extension to these trials would be to assess variety grazing efficiency at participating farms or, at a minimum, surveying farmers for their perception of variety grazing efficiency on their farms. These studies could be compared against the results observed in plot evaluations. Such a system would remove the need to assess grazing efficiency in a number of plot trials at different locations [17], allowing resources within the evaluation system to be better spent.

\section{Conclusions}

Perennial ryegrass grazing efficiency was found to be repeatable, displaying similar levels of correlation to existing perennial ryegrass traits such as herbage yield. The results provide assurance to stakeholders in the forage seed industry when making variety selection decisions. Commercial farmers can be confident that a variety chosen for high grazing efficiency will deliver gains in grazing management on the farm. 


\begin{abstract}
Author Contributions: Conceptualization T.T., L.D. and M.O.; methodology, T.T.; software, T.T.; validation, T.T., L.D. and M.O.; formal analysis, T.T.; investigation, T.T.; data curation, T.T.; writing-original draft preparation, T.T.; writing-review and editing, T.T., L.D. and M.O.; visualization, T.T. and M.O.; supervision, M.O.; project administration, M.O.; funding acquisition, M.O. All authors have read and agreed to the published version of the manuscript.
\end{abstract}

Funding: This research was funded by Irish Dairy Levy Funding administered by Dairy Research Ireland and Vistamilk TP3 Pasture Breeding.

Data Availability Statement: The data presented in the study are available on request from the corresponding author.

Conflicts of Interest: The authors declare no conflict of interest. The funders had no role in the design of the study; in the collection, analyses, or interpretation of data; in the writing of the manuscript, or in the decision to publish the results.

\title{
References
}

1. Hanrahan, L.; McHugh, N.; Hennessy, T.; Moran, B.; Kearney, R.; Wallace, M.; Shalloo, L. Factors associated with profitability in pasture-based systems of milk production. J. Dairy Sci. 2018, 101, 5474-5485. [CrossRef]

2. Horan, B.; Roche, J.R. Defining resilience in pasture-based dairy-farm systems in temperate regions. Anim. Prod. Sci. 2020, 60, 55-66. [CrossRef]

3. Macdonald, K.; Penno, J.; Lancaster, J.; Roche, J. Effect of stocking rate on pasture production, milk production, and reproduction of dairy cows in pasture-based systems. J. Dairy Sci. 2008, 91, 2151-2163. [CrossRef] [PubMed]

4. Byrne, N.; Gilliland, T.J.; McHugh, N.; Delaby, L.; Geoghegan, A.; O'Donovan, M. Establishing phenotypic performance of grass varieties on Irish grassland farms. J. Agric. Sci. 2017, 155, 1633-1645. [CrossRef]

5. Byrne, N.; Gilliland, T.J.; Delaby, L.; Cummins, D.; O’Donovan, M. Understanding factors associated with the grazing efficiency of perennial ryegrass varieties. Eur. J. Agron. 2018, 101, 101-108. [CrossRef]

6. Stewart, A.; Hayes, R. Ryegrass breeding-balancing trait priorities. Ir. J. Agric. Food Res. 2011, 50, 31-46. Available online: http:/ / www.jstor.org/stable/41348154 (accessed on 10 December 2021).

7. Chapman, D.; Edwards, G.; Stewart, A.; McEvoy, M.; O’Donovan, M.; Waghorn, G. Valuing forages for genetic selection: What traits should we focus on? Anim. Prod. Sci. 2015, 55, 869-882. [CrossRef]

8. O'Brien, D.; Moran, B.; Shalloo, L. A national methodology to quantify the diet of grazing dairy cows. J. Dairy Sci. 2018, 101, 8595-8604. [CrossRef] [PubMed]

9. O'Donovan, M.; McHugh, N.; McEvoy, M.; Grogan, D.; Shalloo, L. Combining seasonal yield, silage dry matter yield, quality and persistency in an economic index to assist perennial ryegrass variety selection. J. Agric. Sci. 2016, 155, 556-568. [CrossRef]

10. Tubritt, T.; Shalloo, L.; Gilliland, T.; McHugh, N.; O’Donovan, M. Incorporation of the grazing utilization subindex and new updates to the Pasture Profit Index. J. Dairy Sci. 2021, 104, 10841-10853. [CrossRef] [PubMed]

11. Wims, C.M.; Delaby, L.; Boland, T.M.; O'Donovan, M. Effect of pre-grazing herbage mass on dairy cow performance, grass dry matter production and output from perennial ryegrass (Lolium perenne L.) pastures. Animal 2013, 8, 141-151. [CrossRef] [PubMed]

12. Claffey, A.; Delaby, L.; Galvin, N.; Boland, T.M.; Egan, M. The effect of spring grass availability and grazing rotation length on the production and quality of herbage and milk in early spring. J. Agric. Sci. 2019, 157, 434-448. [CrossRef]

13. Castle, M. A simple disc instrument for estimating herbage yield. Grass Forage Sci. 1976, 31, 37-40. [CrossRef]

14. Tubritt, T.; Delaby, L.; Gilliland, T.; O’Donovan, M. An investigation into the grazing efficiency of perennial ryegrass varieties. Grass Forage Sci. 2020, 75, 253-265. [CrossRef]

15. Gilliland, T.; Mann, R. Effect of sward cutting management on the relative performance of perennial ryegrass varieties. J. Agric. Sci. 2000, 135, 113-122. [CrossRef]

16. Dennis, B.; Frandsen, K. Breeding for improved digestibility in temperate forage grasses. In Plant Breeding Symposium; New Zealand Agronomy Society: Canterbury, New Zealand, 1986; Available online: https:/ / www.agronomysociety.org.nz/uploads / 94803/files/SP5_52._Improved_digestibility_breeding.pdf (accessed on 23 December 2021).

17. Conaghan, P.; Casler, M.; McGilloway, D.; O'Kiely, P.; Dowley, L. Genotype $\times$ environment interactions for herbage yield of perennial ryegrass sward plots in Ireland. Grass Forage Sci. 2008, 63, 107-120. [CrossRef]

18. PastureBase Ireland. Average Grass Growth in Ireland. 2020. Available online: https://pasturebase.teagasc.ie/V2/login.aspx (accessed on 23 December 2021).

19. Gilliland, T.J.; Barrett, P.D.; Mann, R.L.; Agnew, R.E.; Fearon, A.M. Canopy morphology and nutritional quality traits as potential grazing value indicators for Lolium perenne varieties. J. Agric. Sci. 2002, 139, 257-273. [CrossRef]

20. Tubritt, T.; Delaby, L.; Gilliland, T.J.; O'Donovan, M. The relationship between the grazing efficiency and the production, morphology and nutritional traits of perennial ryegrass varieties. J. Agric. Sci. 2020, 158, 583-593. [CrossRef]

21. Balocchi, O.A.; López, I.F. Herbage production, nutritive value and grazing preference of diploid and tetraploid perennial ryegrass cultivars (Lolium perenne L.). Chil. J. Agric. Res. 2009, 69, 331-339. [CrossRef] 
22. Mitchell, K. Growth of pasture species under controlled environment. 1. Growth at various levels of constant temperature. N. Z. J. Sci. Technol. Sect. A 1962, 5, 135-144. [CrossRef]

23. Parsons, A.J.; Edwards, G.R.; Newton, P.C.D.; Chapman, D.F.; Caradus, J.R.; Rasmussen, S.; Rowarth, J.S. Past lessons and future prospects: Plant breeding for yield and persistence in cool-temperate pastures. Grass Forage Sci. 2011, 66, 153-172. [CrossRef]

24. Briske, D. Strategies of plant survival in grazed systems: A functional interpretation. In The Ecology and Management of Grazing Systems; Hodgson, J., Illius, A.W., Eds.; CAB International: Wallingford, UK, 1996; pp. 37-67. 